\title{
The Status and Countermeasures of Rural E- commerce in Shandong Province Based on SWOT Analysis
}

\author{
Peng Sun \\ Office of Educational Administration \\ Qilu Normal University \\ Jinan, China 250013
}

\begin{abstract}
The development process of rural e-commerce in Shandong Province is relatively short, the relevant experience is insufficient, and the policies and systems are still not perfect. At present, while rural e-commerce is developing rapidly, the survival and development faces many challenges. Using SWOT analysis method, the system summarizes the advantages, disadvantages, opportunities and challenges that affect the development of rural e-commerce in Shandong Province, and on this basis, proposes countermeasures to promote the development of rural e-commerce in Shandong Province.
\end{abstract}

Keywords-rural e-commerce; Shandong Province; SWOT analysis

\section{INTRODUCTION}

Rural e-commerce is a new channel for establishing a new rural circulation system, promoting the two-way circulation of consumer goods to the countryside and agricultural products into the city, and expanding urban and rural consumption. It is a new channel to realize the integration of the first, second and third industries, promote the supply-side structural reform, and promote the transformation and development of the county economy. power. Shandong is a major agricultural province in China and a major exporter of agricultural products. The development of rural e-commerce is in good condition and has great potential. In recent years, the rural e-commerce and county e-commerce in the province have developed rapidly with the momentum of Xinghuo, and have achieved a splendid turn from weak to strong. It has become an important engine to promote county and rural economic development, help precision poverty alleviation, and increase farmers' income. It has profoundly affected the consumption habits of the vast number of farmers, farmers and the business model of agriculture-related enterprises. Rural ecommerce allows farmers to directly connect with the market, eliminating the intermediate circulation link and changing the weak position of farmers. The farmers can earn more profits, become a new path for rural economic development, and at the same time achieve new urbanization. Provide new paths and breakthroughs.

As a large agricultural province, Shandong Province's traditional agricultural business information transmission methods and methods directly lead to poor sales of agricultural products, lack of competitiveness in the market, the development of rural e-commerce is not only conducive to the rapid spread of commodity information, but also to change Urban and rural areas have no economic structure break the imbalance of regional economic development, improve the competitiveness of agricultural products market, and create conditions for the growth of farmers' income. Using SWOT analysis method, comprehensively explore the internal and external factors affecting the development of rural e-commerce in the province, and propose countermeasures to promote the development of rural ecommerce in Henan Province.

\section{ANALYSIS OF ADVANTAGES OF RURAL E-COMMERCE} IN SHANDONG PROVINCE

- Location Advantage. Shandong is located in the eastern part of China, with the Beijing-Tianjin-Hebei economic belt in the north, the Yangtze River Economic Belt in the south, the vast Yellow Sea in the east, and the hinterland in the west. It is an important area along the economic corridor of the New Eurasian Continental Bridge and the sea. The important strategic fulcrum of the Silk Road is unique in geographical location.

- Good tranffic. The mileage of railways and highways in the province reached 5,350 kilometers and 5,348 kilometers respectively. All 17 cities have access to railways, and highways cover $96 \%$ of counties and cities. The coastal port has a throughput of 1.34 billion tons and has three 300 million tons of large ports in Qingdao, Rizhao and Yantai. There are 9 civil transport airports, and more than 300 domestic and international routes have been opened. The threedimensional and smooth traffic system provides backbone support for the "One Belt, One Road" cargo circulation and trade. Shandong Province has unique geographic location advantages and logistics center conditions, which will become the unique location and advantages of promoting rural ecommerce. 
- Advantages of agricultural resources. Shandong is a large agricultural province with a wide range of agricultural products. Shandong's grain, vegetables and fruits occupy an important position in the country, and are known as China's Bohai Granary, vegetable garden and fruit basket. In the new era, these rich and characteristic resources constitute the resource advantages of rural e-commerce development in Shandong Province.

\section{ANALYSIS OF RURAL E-COMMERCE DISADVANTAGES} IN SHANDONG PROVINCE

- Rural e-commerce related services are lagging behind. The rural e-commerce in Shandong Province has achieved certain results, but in terms of the overall scale, it is difficult to match the status of the province's agricultural provinces. The sales volume of agricultural products is less than the purchase volume, the deficit is obvious, and it is related to advanced provinces such as Zhejiang and Guangdong. Compared with the policy guidance and the support measures, there is no small gap. At the same time, the basic guarantee of e-commerce for agricultural products in our province is relatively weak, and the multi-level linkage public service system has not been effectively formed. The standardization and branding of agricultural products are low; the logistics and distribution system is not perfect; the e-commerce business of the market is unbalanced, and the share of agricultural products sales is relatively low in the rural e-commerce market in our province; the demonstration is lacking, and the province lacks visibility and influence. The main body of agricultural products e-commerce. All kinds of status quo restrict the rapid development of rural ecommerce in our province.

- Insufficient funds and talent support. Especially in the trading platform, online payment, logistics and distribution, data statistics utilization, public services and other supporting elements of agricultural product e-commerce development, lack of policy and financial support. There is a shortage of e-commerce talents, lack of necessary talents for agricultural products and online sales, and most agricultural products e-commerce entities lack in-depth understanding of e-commerce operation modes, business skills and management methods, product positioning is not suitable, and application capabilities are not strong. The lack of local talents who understand farmers' rural markets and understand e-commerce have become an important obstacle to their rapid development of rural ecommerce. For rural e-commerce, it is more necessary to combine online and offline, and the major e-commerce professionals are not. Understand the rural market.

\section{THE OPPORTUNITY OF RURAL E-COMMERCE IN SHANDONG PROVINCE}

- Policy aspect. At the beginning of 2017, the State Council issued the "Several Opinions on Deepening the Structural Reform of Agricultural Supply Side and Accelerating the Cultivation of New Momentum of Agricultural and Rural Development" (No. 1 Document of the Central Committee of 2017), proposing to promote the development of rural ecommerce and specifying the rural e-commerce The development direction has provided policy support for the development of rural e-commerce. All departments of Shandong Province actively responded to the spirit of the State Council policy, and strive to achieve a unified opening, competition, orderly, honest and law-abiding, safe and reliable, green and environmentally friendly agricultural product e-commerce market system by 2020 , with remarkable development level and sustainable development capability. Enhance and cultivate a group of demonstrations of e-commerce typical of agricultural products with outstanding effects and extensive influence. The total amount of e-commerce transactions of agricultural products reached 100 billion yuan.

- Third-party e-commerce platform. Internet giants such as Alibaba, Jingdong and Suning Tesco actively deployed the rural market and "carrying capital to seize the market". The profit prospects of rural ecommerce are generally optimistic. For example, Alibaba officially launched the "Thousands of Counties and Villages" program in 2014. It is expected to spend 10 billion RMB in the next 3-5 years, establish 1,000 county-level operation centers and 100,000 village-level service stations, and build a rural e-commerce service system. The rookie network began to lay out the rural logistics network, the future goal is to get 800 million rural population; the online village Amoy APP, recruiting "village tao partners."

At the beginning of 2015, Jingdong began to establish a self-operated "county-level service center" in the country, and at the same time opened a "Jingdong Bang Service Store" in the form of joining. The county-level service center undertakes the responsibility of distribution, customer experience, rural extension staff training, publicity and product physical display. "Jingdong Gang Service Shop" only operates the home appliance business. It is a cooperative relationship with JD. It carries the Jingdong selfoperated home appliance business and mainly solves the problem of distribution and installation.

\section{THE THREAT OF RURAL E-COMMERCE IN SHANDONG PROVINCE}

Competing competition in neighboring provinces. In recent years, the whole country and even the provinces have realized that the e-commerce industry has greatly promoted the regional social and economic development, and have formulated corresponding policies to promote the 
development of e-commerce, so that the provinces will compete with each other. For example, competition for investment areas of major e-commerce companies, competition for certain reform pilots, and competition for human resources. For Henan Province, the surrounding provinces, especially Hebei, Henan, Jiangsu and other provinces will be the main competitors. Competition from neighboring provinces may lead to the outflow of resources for rural e-commerce development in Shandong Province, affecting rural e-commerce in Shandong Promotion.

\section{COUNTERMEASURES AND RECOMMENDATIONS}

- It is necessary to increase rural e-commerce policy support. Increase funding support, focus on supporting agricultural product e-commerce demonstration, information into the village, brand cultivation, talent training and public welfare construction projects; improve land use, water, electricity, taxation, investment, finance and other policies for the development of agricultural products e-commerce Establish a talent introduction mechanism, accelerate the introduction of a batch of high-end talents for e-commerce of agricultural products; further broaden the channels for investment and financing of e-commerce for agricultural products, strengthen the guidance and role of financial support for social investment, and form a partnership between government-led investment and social capital investment. Financing mechanism; fostering and developing venture capital investment, and strengthening capital support for independent innovation and entrepreneurship of agricultural products.

- It is necessary to improve the development environment of rural e-commerce and accelerate the construction of information infrastructure. Strengthen rural circulation infrastructure construction and increase rural broadband penetration rate. In terms of Internet infrastructure construction, it is more important for operators to provide universal service compensation mechanisms. After establishing such a mechanism, it is possible for enterprises to build more Internet base stations in rural areas and achieve network popularity. Strengthening rural road construction and improving rural logistics distribution capacity The government should give broad and powerful guidance and support, increase the construction of rural information infrastructure, improve transportation, information, production and distribution, cold chain and other related facilities, and encourage rural commercial enterprises to build and distribute. Center, develop third-party distribution, etc., to improve circulation efficiency.

- Vigorously cultivate rural electric merchants and encourage entrepreneurship through the Internet. Carry out rural informationization knowledge training and cultivate information talents. We should make full use of the advantages of computer networks, combine other means of communication, vigorously implement distance education, continuously improve the quality of workers, strengthen farmers' information awareness, and cultivate high-quality new farmers. In addition, various professional talents who understand the business should be enriched into the rural informationization team to form a team with reasonable structure and good quality to provide information services for the rural areas. In terms of personnel training, training courses can be carried out by enterprises to the countryside, or the government can provide training subsidies, and farmers can find training institutions for training. Establish information consultation service institutions at all levels, guide and train farmers to use various information facilities, and master the various skills of e-commerce.

\section{CONCLUSION}

At present, rural e-commerce in Shandong has become an important support for building a new type of agricultural system, promoting agricultural transformation and upgrading, and assisting in poverty alleviation. The provincial government attaches great importance to it and insists on promoting it in a comprehensive manner. The development of rural e-commerce in Shandong, especially the upstream aspect of agricultural products, has great potential. Rural ecommerce has become an important support for building a new rural circulation system, transforming agricultural development methods, and assisting in poverty alleviation.

\section{REFERENCES}

[1] Liao Wei, Wang Mingyu, Cross-border E-commerce Analysis and Trend Analysis[J]. electronic Business, 2014(2)

[2] Shao Jihong. Research on China's mobile e-commerce market value chain [J]. Planning and decision making, 2009(14)

[3] Zhang Hongjie. Development of Characteristic Agriculture in Henan Province SWOT analysisy [J]. Journal of Shandong Agricultural Management Cadre College, 2011(5)

[4] Wang Xiangdong. A new model for rural economic and social transformation

[5] Sand collection Sub-commerce as an example [J]. Engineering Research, 2013(2) 